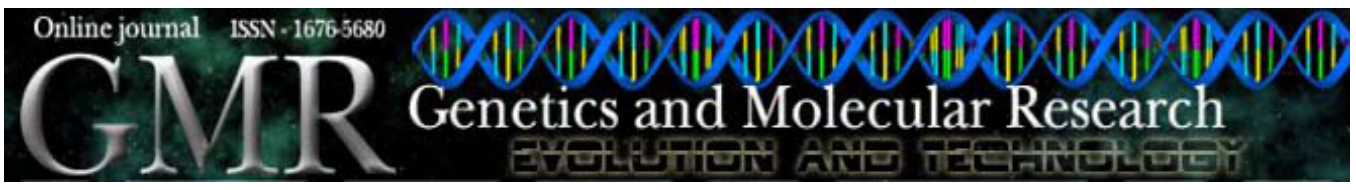

\title{
Simple DNA extraction protocol for a 16S rDNA study of bacterial diversity in tropical landfarm soil used for bioremediation of oil waste
}

\author{
B.M. Maciel, A.C.F. Santos, J.C.T. Dias, R.O. Vidal, R.J.C. Dias, \\ E. Gross, J.C.M. Cascardo and R.P. Rezende \\ Departamento de Ciências Biológicas, \\ Universidade Estadual de Santa Cruz, Salobrinho, Ilhéus, BA, Brasil \\ Corresponding author: R.P. Rezende \\ E-mail: rachel@uesc.br
}

Genet. Mol. Res. 8 (1): 375-388 (2009)

Received November 27, 2008

Accepted February 17, 2009

Published March 31, 2009

\begin{abstract}
Landfarm soil is used to bioremediate oil wastes from petrochemical industries. We developed a simplified protocol for microbial DNA extraction of tropical landfarm soil using only direct lysis of macerated material. Two samples of tropical landfarm soil from a Brazilian refinery were analyzed by this protocol (one consisted of crude oilcontaminated soil; the other was continuously enriched for nine months with petroleum). The soil samples were lysed by maceration with liquid nitrogen, eliminating the need for detergents, organic solvents and enzymatic cell lysis. Then, the DNA from the lysed soil sample was extracted using phenol-chloroform-isoamyl alcohol or guanidium isothiocyanate, giving high DNA yields (more than $1 \mu \mathrm{g}$ DNA/g soil) from both soil types. This protocol compared favorably with an established method of DNA template preparation that included mechanical, chemical and enzymatic treatment for cell lysis. The efficiency of this extraction protocol was confirmed by polymerase chain reaction amplification of the $16 \mathrm{~S}$ rRNA gene, denaturing gradient gel electrophoresis and cloning assays. Fifty-one different clones were obtained; their sequences were classified into at least seven different phyla of the Eubacteria group (Proteobacteria - alpha, gamma and delta, Chloroflexi, Actinobacteria, Acidobac-
\end{abstract}


teria, Planctomycetes, Bacteroidetes, and Firmicutes). Forty percent of the sequences could not be classified into these phyla, demonstrating the genetic diversity of this microbial community. Only eight isolates had sequences similar to known sequences of 16S rRNA of cultivable organisms or of known environmental isolates and therefore could be identified to the genus level. This method of DNA extraction is a useful tool for analysis of the bacteria responsible for petroleum degradation in contaminated environments.

Key words: Microbial DNA; Bacterial diversity; Direct lysis; Petroleum degradation; Cloning assay; DGGE

\section{INTRODUCTION}

"Landfarming" is a method used by petrochemical industries for oil waste bioremediation. It is a natural source of microorganisms capable of degrading petroleum-derived byproducts (Ausma et al., 2003). The study of the bacterial community in landfarm soil helps elucidate the microbial consortium responsible for petroleum biodegradation (Fernandez et al., 1999). Nevertheless, it is well known that only a small percentage of bacteria can be cultivated (Amann et al., 1995), with the major proportion remaining inaccessible to investigation. Thus, culture-independent methods allow us to determine microbial diversity in environmental samples, important in bioremediation processes (Juck et al., 2000).

There are many published methods for DNA extraction from soil and sediments in studies on autochthonous bacteria (e.g., Ogram et al., 1987; Steffan et al., 1988; Tsai and Olson, 1991, 1992; Picard et al., 1992; Smalla et al., 1993; Berthelet et al., 1996; Zhou et al., 1996; Krsek and Wellington, 1999; Wechter et al., 2003), where these methods are not universally applicable. The range of methods described probably reflects the heterogeneity of the soils and the nature of subsequent analyses of the DNA (Zhou et al., 1996). There are two approaches for extracting microbial DNA: ex situ, by cell extraction methods or in situ, by direct lysis methods. Cell lysis generally combines detergent and lytic enzymes. Chemical or enzymatic lysis are relatively gentle, producing limited DNA shearing, but the amount of DNA is not representative of the microbial community because these methods do not completely penetrate the soil. Direct lysis may give more uniform cell disruption, reaching a larger number of different cells, but the disadvantage is that it tends to shear the DNA (Roose-Amsaleg et al., 2001). Usually, the mechanical processes that promote cell lysis in environmental samples are bead-beating, sonication, vigorous shaking, and thermal treatments (Krsek and Wellington, 1999), and the use of these methods alone is inefficient for complete cell lysis. The isolated use of a physical lysis method has some limitations, and it can enable the extraction of humic and fulvic acids. These contaminants can interfere with or prevent subsequent molecular analysis, and thus, a reliable purification step is necessary to minimize the contamination of the DNA with these and other organic components (Krsek and Wellington, 1999; Roose-Amsaleg et al., 2001).

The identification of ribosomal RNA as a premier molecule for evaluating evolutionary relationships and the application of molecular techniques to microbial systematics has revolutionized the concept of phylogenetic relationships among bacteria (Woese, 1987; Olsen et al., 1994). Indeed, the application of this phylogenetic knowledge to microbial ecology has 
contributed enormously to microbial diversity studies. Prior to the phylogenetic revolution and the development of culture-independent molecular approaches, truer estimates of diversity of microbial communities could not be made (Amann et al., 1995). Such studies are becoming common and many bacteria have been described based on their 16S rRNA gene sequences.

We report here a protocol developed and tested for microbial DNA extraction directly from a landfarm soil using only mechanical lysis by maceration with liquid nitrogen and further polymerase chain reaction (PCR) for amplification of the 16S rRNA gene. PCR amplification was used as a parameter in evaluating DNA purity because Taq polymerase is sensitive to humic acid contamination and because PCR amplification is often used in the study of extracted soil DNA. PCR fragments were used for denaturing gradient gel electrophoresis (DGGE) analysis and cloning assays to validate the method and for further study of the microbial community involved in petroleum degradation.

\section{MATERIAL AND METHODS}

\section{Soil source}

A Brazilian landfarm soil (Table 1) contaminated with petroleum waste from Landulpho Alves Refinery, Camaçari, Bahia, was sampled from the surface to a depth of $10 \mathrm{~cm}$, sealed in an aluminum flask and transported to the Environment Quality Laboratory of the Universidade Estadual de Santa Cruz in Ilhéus, Bahia State, to be processed.

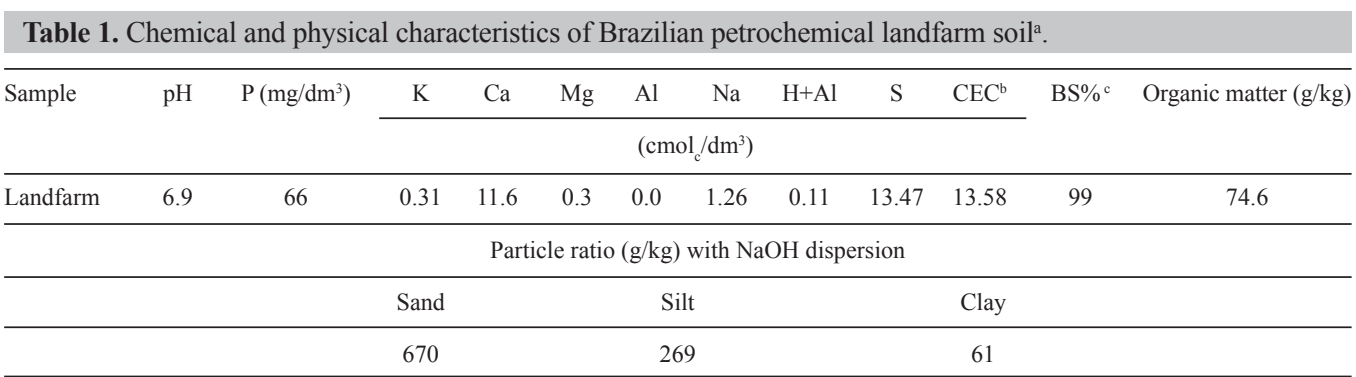

a Soil analysis made by Embrapa Solos (Cruz das Almas, Bahia, Brazil). ${ }^{\mathrm{b} C a t i o n}$ exchange capacity. ${ }^{\mathrm{c} B a s e}$ saturation.

\section{Soil sampling}

Two samples of landfarm soil were analyzed. One, labeled Soil 1, consisted of crude oil-contaminated soil. The other, labeled Soil 2, was continuously enriched for 9 months with petroleum and a minimal medium consisting of $0.1 \% \mathrm{w} / \mathrm{v} \mathrm{KH}_{2} \mathrm{PO}_{4}, 0.1 \% \mathrm{w} / \mathrm{v} \mathrm{K}_{2} \mathrm{HPO}_{4}, 0.1 \%$ $\mathrm{w} / \mathrm{v} \mathrm{NH}_{4} \mathrm{NO}_{3}, 0.05 \% \mathrm{w} / \mathrm{v} \mathrm{MgSO}_{4}, 0.001 \% \mathrm{v} / \mathrm{v}$ saturated $\mathrm{FeSO}_{4}$ solution, $0.001 \% \mathrm{v} / \mathrm{v}$ saturated $\mathrm{CaCl}_{2}, \mathrm{pH} 7.0$ (Li et al., 2000) and kept under constant agitation at $120 \mathrm{rpm}$ at room temperature $\left( \pm 28^{\circ} \mathrm{C}\right)$ with the objective of selecting only those microorganisms adapted to petroleum and responsible for its degradation. 


\section{DNA extraction}

Triplicates of each soil sample were used in two different protocols for DNA extraction. Two of the soil samples were first washed three times with $3 \mathrm{~mL}$ TE buffer 50/50 (50 mM Tris-HCl, $50 \mathrm{mM}$ EDTA, $\mathrm{pH}$ 8.0). This soil washing aimed at the removal of debris. The buffer was added and the samples were centrifuged to pellet soils. In the first protocol (Protocol I-A), the lysis step was performed only by mechanical lysis by soil maceration with liquid nitrogen. Approximately $10 \mathrm{~mL}$ liquid nitrogen was added to the soil sample and a vigorous maceration using a mortar and pestle, for approximately $30 \mathrm{~s}$, was performed (modified from Volossiouk et al., 1995). This procedure was repeated twice to disaggregate soil particles until a fine powder remained. The soil was then transferred to a 10.0-mL plastic tube to which $2 \mathrm{~mL}$ TE buffer 50/50 and an equivalent volume of phenol-chloroform-isoamyl alcohol (25:24:1) were added, and the mixture was gently vortexed for $1 \mathrm{~min}$. The mixture was centrifuged at $2700 \mathrm{~g}$ at $4^{\circ} \mathrm{C}$ for $10 \mathrm{~min}$ and the supernatant collected. To precipitate DNA, 0.7 vol. cooled isopropanol and $1 / 10$ vol. $3 \mathrm{M}$ sodium acetate were added to the supernatant. The mixture was gently mixed (5-10 times) and kept at $-20^{\circ} \mathrm{C}$ overnight. The sample was centrifuged at $2700 \mathrm{~g}$ for $10 \mathrm{~min}$, and the pellet was washed three times with cold $70 \%$ ethanol and then resuspended in 100 $\mu \mathrm{L}$ TE buffer 10/0.1 (10 mM Tris-HCl, 0.1 mM EDTA, pH 8.0). After the washing step, the extracted DNA was then purified in mini-columns of SEPHADEX ${ }^{\circledR}$ G-200 (Pharmacia, Sweden). In order to compare the two extraction procedures, a variation of the protocol described above (Protocol $I-B$ ) was conducted using $1 \mathrm{~mL} 5 \mathrm{M}$ guanidium isothiocyanate added to $1 \mathrm{~mL}$ chloroform-isoamyl alcohol (24:1) instead of phenol-chloroform-isoamyl alcohol.

The second protocol (Protocol II) was performed based on the method described by Krsek and Wellington (1999), with some modifications. After the washing step of the soil with TE buffer 50/50, enzymatic, chemical and mechanical lysis was performed. For the enzymatic lysis, the sample was suspended in $2 \mathrm{~mL}$ of a lysozyme solution $(150 \mathrm{mM} \mathrm{NaCl}, 100 \mathrm{mM}$ EDTA, $5 \mathrm{mg} / \mathrm{mL}$ lysozyme). The tube was inverted several times to mix the contents and placed in a $37^{\circ} \mathrm{C}$ water bath for $2 \mathrm{~h}$. Subsequently, $500 \mu \mathrm{L}$ proteinase $\mathrm{K}(2.5 \mathrm{mg} / \mathrm{mL})$ was added, and the contents of the tube gently mixed and placed in a $55^{\circ} \mathrm{C}$ water bath for $15 \mathrm{~min}$. For the chemical lysis, $2 \mathrm{~mL}$ SDS solution ( $500 \mathrm{mM} \mathrm{NaCl}, 500 \mathrm{mM}$ Tris-HCl, 10\% w/v SDS) was added to the tube and the contents mixed by inversion several times for $5 \mathrm{~min}$. Finally, for the mechanical lysis process, the samples were subjected to three cycles of freezing in liquid nitrogen and thawing at $100^{\circ} \mathrm{C}$. An equivalent volume $(4.5 \mathrm{~mL})$ of phenol-chloroform-isoamyl alcohol (25:24:1) was added and the mixture gently vortexed for $1 \mathrm{~min}$. The DNA precipitation and purification steps were then performed as previously described.

For visualizing the DNA extracts, $10 \mu \mathrm{L}$ of each extract was electrophoresed on $1 \%$ agarose gels in $1 \mathrm{X}$ TBE buffer, which were then stained with ethidium bromide and examined under UV light.

\section{Yield and purity of DNA}

After purification, DNA was quantified at $260 \mathrm{~nm}$ using a scanning SPD-M6A (Shimadzu ${ }^{\mathrm{TM}}$ ) spectrophotometer equipped with a UV detector. DNA was also quantified by gel electrophoresis in Tris-borate-EDTA (TBE) buffer containing $0.5 \mu \mathrm{g} / \mathrm{mL}$ ethidium bromide on $1 \%$ agarose gel with a known concentration of lambda phage DNA. The DNA yields were 
estimated on the basis of three replicate determinations. The purity of DNA extracts was assessed spectrophotometrically by calculating the $\mathrm{A}_{260} / \mathrm{A}_{280}$ ratio.

\section{PCR conditions and primers}

Two sets of primers were used to amplify regions specific for almost all eubacterial $16 \mathrm{~S}$ sequences. A region of approximately $360 \mathrm{bp}$ from the $16 \mathrm{~S}$ rRNA gene was amplified using the primers F984 (5'-GCCCGGGGCGCGCCCCGGGCGGGGCGGG GGCACGGGGGGAACGCGAAGAACCTTAC-3') and R1378 (5'-CGGTGTGTACAAGG CCCGGGAACG-3') (Heuer et al., 1997). The underlined sequence in F984 indicates the GC clamp required for DGGE analysis (Sheffield et al., 1989).

For cloning and phylogenetic analysis, a region of approximately $1500 \mathrm{bp}$ from the 16S rRNA gene was amplified using the primers F27 (5'-AGAGTTTGATCMGGC TCAG-3') and R1525 (5'-AAGGAGGTGWTCCARCC-3') (Lane, 1991). Each 50- $\mu$ L PCR mixture contained $10 \mathrm{ng}$ soil DNA, 1X PCR buffer, $200 \mu \mathrm{M}$ of each deoxyribonucleoside triphosphate, $0.2 \mu \mathrm{M}$ of sense and antisense primers, $3.7 \mathrm{mM} \mathrm{MgCl}, 0.4 \mathrm{mg} / \mathrm{mL}$ BSA and 2.85 U Taq DNA polymerase (Taq DNA Polymerase in Storange Buffer B, PROMEGA ${ }^{\circledR}$, \#M1665). The amplification cycle consisted of an initial denaturation step of $5 \mathrm{~min}$ at $94^{\circ} \mathrm{C}$, followed by 35 cycles of $1 \mathrm{~min}$ at $94^{\circ} \mathrm{C}, 2 \mathrm{~min}$ at $60^{\circ} \mathrm{C}$ and $1 \mathrm{~min}$ at $72^{\circ} \mathrm{C}$ and a final extension step of $30 \mathrm{~min}$ at $72^{\circ} \mathrm{C}$. Salmonella enterica sorotype Rubislaw lysis was used as a positive control in the PCR assay, while template DNA was omitted from the reaction mixture for the negative control. For visualizing PCR products, $5 \mu \mathrm{L}$ of the suspension was electrophoresed on $1 \%$ agarose gels in $1 \mathrm{X}$ TBE buffer, which were then stained with ethidium bromide and examined under UV light. Bands were excised, and DNA was purified from gel slices using the PCR Clean-up System Kit (PROMEGA ${ }^{\circledR}$ ).

Duplicate DNA extracts were used with the same PCR master-mixes to ensure impartial amplifications, and all amplifications were performed simultaneously.

\section{DGGE analysis}

Denaturing gradient gel electrophoresis from Soil 1 and Soil 2 was performed using the D-code ${ }^{\circledR}$ Universal Mutation System (Bio-Rad, Hemel Hempstead, UK). The rDNA sequences amplified by F984-GC clamp and R1378 primers $(6 \mu \mathrm{g})$ were analyzed on an 8\% $(\mathrm{w} / \mathrm{v})$ polyacrylamide gel (37.5:1 acrylamide:bisacrylamide) consisting of a 35-70\% denaturing concentrate $(100 \%$ denaturing agent corresponds to $7 \mathrm{M}$ urea and $40 \%(\mathrm{v} / \mathrm{v})$ deionized formamide). The gels were run in $0.5 \mathrm{X}$ TAE buffer $(20 \mathrm{mM}$ Tris acetate, $\mathrm{pH} 7.4,10 \mathrm{mM}$ sodium acetate, $0.5 \mathrm{mM}$ disodium EDTA) at a constant voltage of $60 \mathrm{~V}$ for $18 \mathrm{~h}$ at $60^{\circ} \mathrm{C}$. Bands were visualized by staining with silver nitrate, and images were acquired using Image Master 3D Platinum software (GE Healthcare, USA), at a spatial resolution of 300 d.p.i. Each band was considered an operational taxonomical unit (OTU).

\section{Cloning procedures}

The rDNA sequences amplified by F27 and R1525 primers were purified with the Concert rapid PCR purification kit (Life Technologies ${ }^{\circledR}$ ), then ligated into a plasmid vector 
pTZ57R/T (Fermentas ${ }^{\circledR}$ ) and transformed into electrocompetent cells (E. coli DH10 - Electromax ${ }^{\mathrm{TM}}$ Competent Cells, Invitrogen), all following manufacturer instructions. The transformed cells were spread on Luria-Bertani plates containing $50 \mu \mathrm{g} / \mathrm{mL}$ ampicillin, $25 \mu \mathrm{g} /$ $\mathrm{mL}$ X-Gal (5-bromo-4-chloro-3-indolyl-b-D-galactopyranoside), $50 \mu \mathrm{g} / \mathrm{mL}$ IPTG (isopropylb-D-thiogalactopyranoside) and incubated overnight at $37^{\circ} \mathrm{C}$. Blue and white colonies were screened to ensure the absence and presence of inserts, respectively, by performing colony PCR with vector-specific M13 primers (forward 5'-GTAAAACGACGGCCAGT-3' and reverse 5'-CAGGAAACAGCTATGAC-3'). White colonies were selected to construct the 52 clone libraries. Plasmid DNA was prepared with a Qiagen Plasmid Kit (Qiagen ${ }^{\circledR}$ ) and sequenced using M13 primers in an Amersham Bioscience MegaBACE $1000^{\mathrm{TM}}$ capillary sequencer.

\section{Phylogenetic analysis}

Sequences were trimmed to remove vector sequences. Prior to phylogenetic analysis, the clones were checked for chimeras using the Chimera Check program of the Ribosomal Database Project. All sequences were compared to those available in a public database (Ribosomal Database Project release 9.43 [RDP] (Cole et al., 2005) in order to validate the sequences, and those highly similar were included in the analysis.

A sample of 26 sequences from landfarm soil were aligned with ClustalW (version 1.83; Thompson et al., 1994) and manually corrected. The clones sequenced in different regions in $16 \mathrm{~S}$ rDNA gene were excluded from the multiple alignment. Phylogenetic analysis was performed with the PHYLIP phylogeny inference package (version 3.66; Felsenstein, 1989) by the maximum-likelihood method with the DNAMLK program. The stability of branches was assessed by the bootstrap method with SEQBOOT (500 replicates), DNAMLK and CONSENSE programs.

The taxonomic analysis of the clones was conducted in the Naive Bayesian Classifier, a classification algorithm described by Wang et al. (2007) for classifying bacterial 16S rRNA sequences in the new Bergey's bacterial taxonomy (Cole et al., 2005). This method works well with partial sequences, a mean of approximately $700 \mathrm{bp}$, and gives an accuracy of more than $99.2 \%$ classified to phylum, $98.4 \%$ to class, $96.6 \%$ to order, $93.0 \%$ to family, and $87.7 \%$ to genus, using the default threshold of $80 \%$. The Bayesian Classifier uses a training set to determine the taxonomy search for the patterns of each taxon. For each rank assignment, the Classifier automatically estimates the classification reliability using bootstrapping. Ranks where sequences could not be assigned with a bootstrap confidence estimate above the threshold are displayed under an artificial "unclassified" taxon. The sequences that were possible to classify were labeled with information about their hierarchical taxonomy. The sequences determined in this study are under the accession numbers EF088431-EF088482 in the GenBank database.

\section{RESULTS}

Direct lysis for DNA extraction by maceration with liquid nitrogen (described in Protocols $I-A$ and $I-B$ ) proved to be very efficient in providing large amounts of DNA. This method eliminates the use of detergents, organic solvents and enzymatic cell lysis, yielding, on average, $1.25 \mu \mathrm{g}$ DNA/g soil (Table 2) from both soils after the purification step (Figure 1A - lanes I, II, II). 
Table 2. Summary of all protocols tested in this study for DNA extraction of Brazilian petrochemical landfarm soil.

\begin{tabular}{|c|c|c|c|}
\hline \multirow[t]{2}{*}{ Treatment } & \multicolumn{3}{|c|}{ Protocols $^{\mathrm{a}}$} \\
\hline & I-A & I-B & II \\
\hline \multicolumn{4}{|l|}{ i. Cell lysis } \\
\hline Mechanical & Maceration with liquid $\mathrm{N}_{2}$ & Maceration with liquid $\mathrm{N}_{2}$ & $\begin{array}{l}\text { Three alternate cycles of } \\
\text { freezing in liquid nitrogen and } \\
\text { thawing at } 100^{\circ} \mathrm{C} \text { water bath }\end{array}$ \\
\hline Chemical & None & None & SDS \\
\hline Enzymatic & None & None & Proteinase K/lysozyme \\
\hline ii. DNA separation & $\begin{array}{l}\text { Phenol-chloroform- } \\
\text { isoamyl alcohol }\end{array}$ & Guanidium isothiocyanate & $\begin{array}{l}\text { Phenol-chloroform- } \\
\text { isoamyl alcohol }\end{array}$ \\
\hline iii. Precipitation & Isopropanol + sodium acetate & Isopropanol + sodium acetate & Isopropanol + sodium acetate \\
\hline iv. Purification & Commercial kit & Commercial kit & Commercial kit \\
\hline \multicolumn{4}{|l|}{ Results } \\
\hline Soil quantity & $2 \mathrm{~g}$ & $2 \mathrm{~g}$ & $2 \mathrm{~g}$ \\
\hline DNA yield ${ }^{\mathrm{b}}(\mu \mathrm{g} / \mathrm{g}$ soil $)$ & 1.25 & $1.00^{\mathrm{c}}$ & Sheared DNA \\
\hline Purity d ${ }^{2600280)}$ & $1.72 \pm 0.02$ & $1.35 \pm 0.04$ & $\mathrm{ND}^{\mathrm{e}}$ \\
\hline PCR analysis & Yes & Yes & No \\
\hline
\end{tabular}

${ }^{a}$ See Methods. ${ }^{b}$ Mean of three DNA extractions of each soil (crude landfarm soil and landfarm soil constantly enriched with petroleum). ${ }^{~}$ Result obtained only for landfarm soil constantly enriched with petroleum. ${ }^{\mathrm{d}}$ Mean of three DNA extractions (of each soil) \pm 1 standard deviation. ${ }^{\mathrm{e} A b s o r b a n c e}$ ratio for purified DNA was not determined.

The use of phenol-chloroform-isoamyl alcohol (25:24:1) for DNA extraction was successful for both samples, unlike guanidium isothiocyanate, which was efficient only for soil 2 (Figure 1A - lane III). Besides the variation of the protocol, where either phenol-chloroformisoamyl alcohol or guanidium isothiocyanate were used for DNA extraction, other treatments for mechanical, chemical and enzymatic lysis (Protocol II) were also tested and compared to direct lysis only by maceration with liquid nitrogen. This protocol provided a large amount of DNA shearing from Soil 1, where the DNA was difficult to quantify (Figure 1A - lane IV) and of insufficient quality for use in PCR analysis. DNA could not be extracted from Soil 2 using this protocol. The results of the protocols are summarized and compared in Table 2.

DNA extraction by Protocol I provided a good yield of DNA, which could be used in 16S gene amplification (Figures 2 and 3). Satisfactory amplification products were obtained after adding large quantities of Taq DNA polymerase $(2.85 \mathrm{U})$, in addition to the $0.4 \mathrm{mg} / \mathrm{mL}$ BSA to protect the enzyme, indicating that the DNA samples were not totally free of PCR inhibitors. The amplification products were satisfactory for DGGE and cloning analysis.

The DGGE banding patterns revealed 21-23 predominant OTUs, represented by distinguishable bands (Figure 2). The intensity of the bands corresponds to the number of predominant members in the microbial communities.

For a first screening, 52 clones were sequenced of which only one was classified as duplicated or almost identical, giving a total of 51 different clones. Of the 51 different analyzed sequences, two sequences showed chimeras (EF088440 from clone 15 and EF088449 from clone 17) and were excluded from taxonomical analysis. Nevertheless, for phylogenetic analysis only the region of the sequences that could be aligned in the same portion of the 

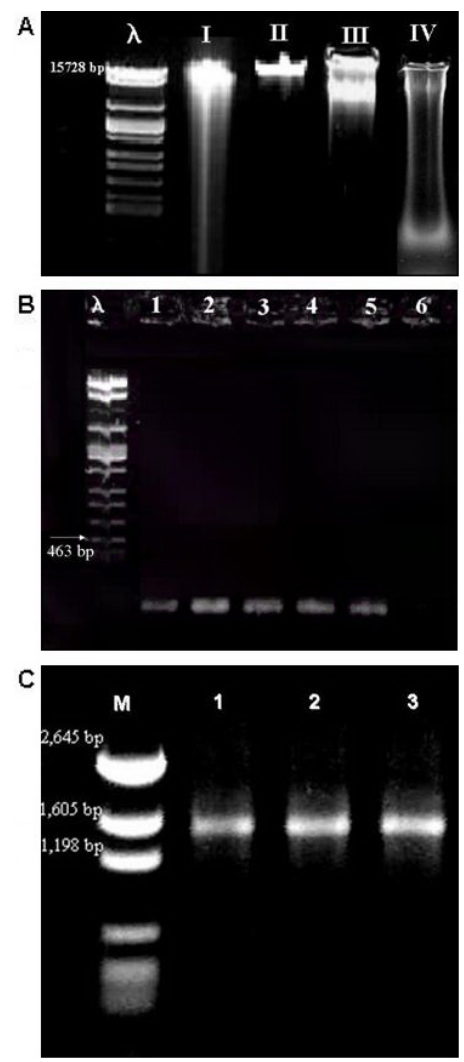

Figure 1. A. DNA extracted from landfarm soil contaminated with petroleum waste after electrophoresis on $1.2 \%$ agarose gel. Lane $I=$ Crude landfarm soil (Soil 1) extracted with phenol-chloroform-isoamyl alcohol (25:24:1) by the delineated Protocol I-A. Lane II = Landfarm soil constantly enriched with petroleum and minimal medium (Soil 2) extracted with phenol-chloroform-isoamyl alcohol (25:24:1), Protocol I-A. Lane III = Landfarm soil constantly enriched with petroleum and minimal medium (Soil 2) extracted with guanidium isothiocyanate plus chloroformisoamyl alcohol (24:1), by the delineated Protocol I-B. The DNAs shown in lanes I, II, and III were obtained only by direct lysis treatment by soil maceration with liquid nitrogen. Lane $I V=$ Crude landfarm soil (Soil 1) obtained by mechanical, chemical and enzymatic treatments for cell lysis and extracted with phenol-chloroform-isoamyl alcohol (25:24:1) by the delineated Protocol II. Lane $\lambda=$ Molecular weight marker (bacteriophage $\lambda$ DNA digested by EcoRI, HindIII and BamHI). B. Polymerase chain reaction (PCR) amplification products targeting the 16S rRNA gene in soil DNA, using primers F984 and R1378. Lanes 1 and 2 = PCR product of approximately $360 \mathrm{bp}$ of $16 \mathrm{~S}$ rRNA gene from DNA of crude landfarm soil (Soil 1) extracted with phenol-chloroform-isoamyl alcohol (25:24:1) by the delineated Protocol I-A. Lane $3=$ PCR product of $16 \mathrm{~S}$ rRNA gene from DNA of landfarm soil constantly enriched with petroleum and minimal medium (Soil 2) extracted according to Protocol I-A. Lane 4 = PCR product of 16S rRNA gene from DNA of Soil 2 extracted with guanidium isothiocyanate plus chloroform-isoamyl alcohol (24:1), by the delineated Protocol I-B. Lane 5 = Salmonella enterica sorotype Rubislaw lysis as positive control. Lane $6=$ Negative control (water). Lane $\lambda=$ Molecular weight marker (bacteriophage $\lambda$ DNA digested by EcoRI, HindIII and BamHI). C. PCR amplification products targeting the 16S rRNA gene in soil DNA, using primers F27 and R1525. DNA was extracted with phenolchloroform-isoamyl alcohol (25:24:1) by the delineated Protocol I-A. Lane 1 = PCR product of approximately $1500 \mathrm{bp}$ of 16S rRNA gene from DNA of crude landfarm soil (Soil 1). Lane 2 = PCR product of 16S rRNA gene from DNA of landfarm soil constantly enriched with petroleum and minimal medium (Soil 2). Lane 3 = PCR product of 16S rRNA gene from DNA of Atlantic Rainforest. Lane $M=$ Molecular weight marker (pGEM DNA Marker, PROMEGA ${ }^{\circledR}$ ). 


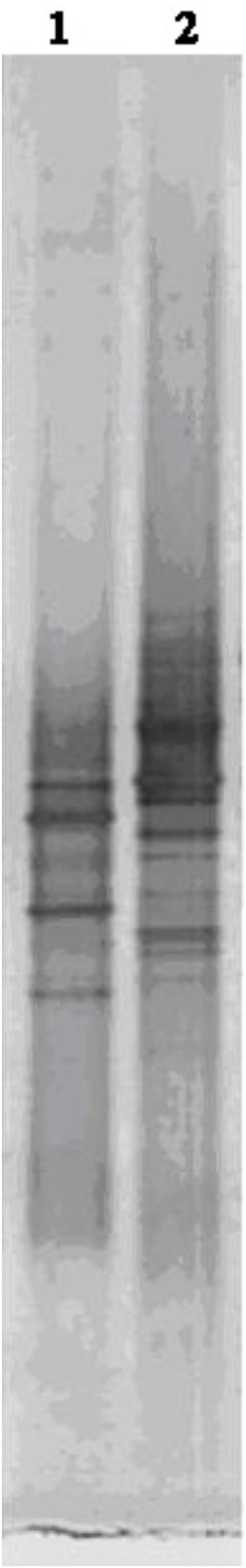

Figure 2. Denaturing gradient gel electrophoresis analyses of $16 \mathrm{~S}$ rDNA fragments of different soils obtained after DNA extraction with Protocol $I-A$ and polymerase chain reaction amplification with primers $984 \mathrm{FGC}$ and $1378 \mathrm{R}$. Lane 1 = Landfarm-enriched soil; Lane 2 = landfarm soil. 


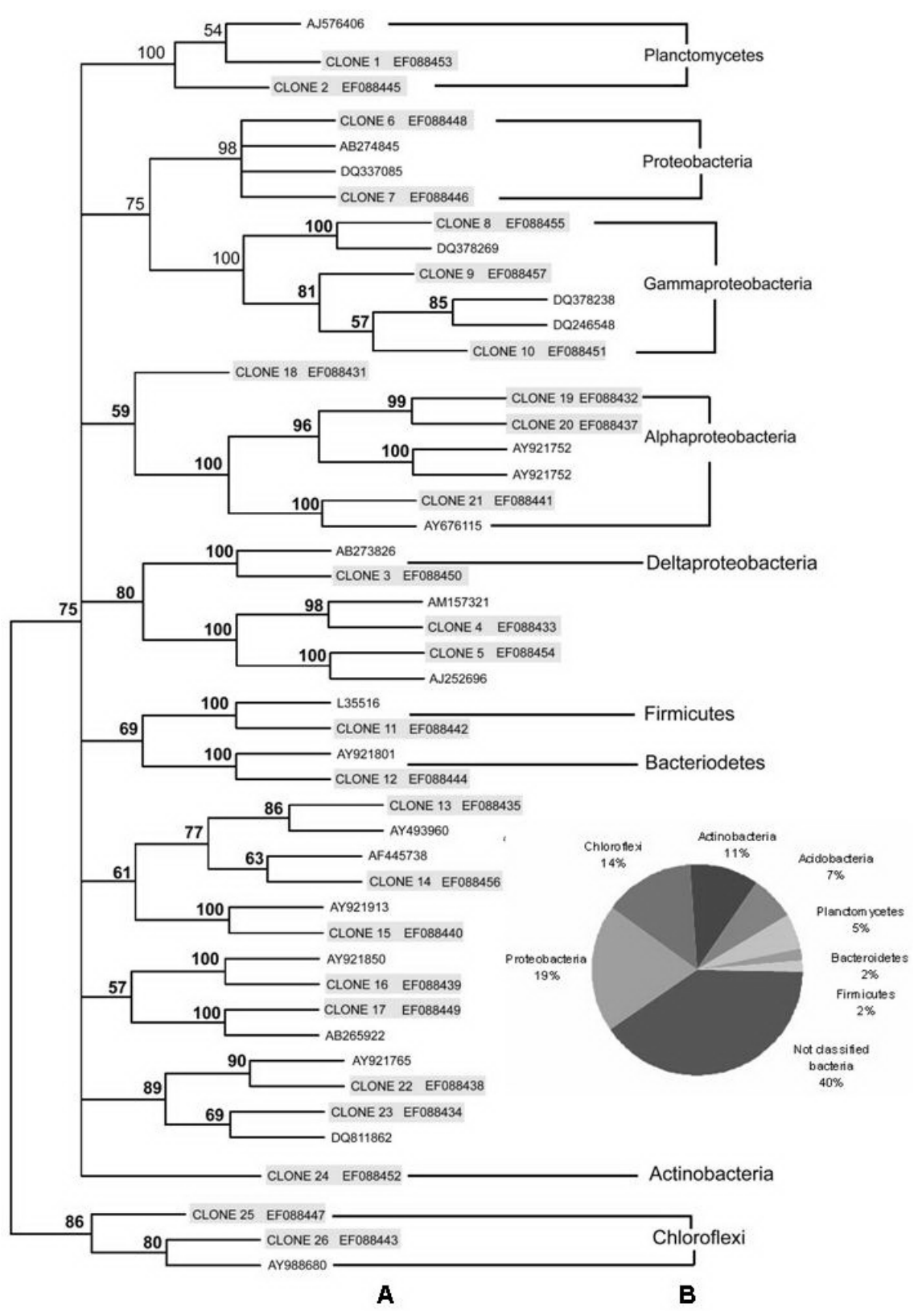

Figure 3. A. Phylogenetic tree of $16 \mathrm{~S}$ rDNA sequences from landfarm soil. The tree was constructed using the neighbor-joining method. The scale bar is in fixed nucleotide substitutions per sequence position. The percentage of 500 bootstrap resamplings that support branching points above $70 \%$ confidence is indicated and bootstrap values (in percentages) are indicated at branching points. B. Distribution of 49 bacterial clones by phylum. The clones were compared to reference sequences after analyses in RDB (Ribosomal Database Project). The accession numbers in the dendrogram correspond to the accession numbers of the sequences obtained from GenBank database. 
rDNA 16S gene was used. Of the 49 clones analyzed taxonomically, $60 \%$ could be classified in region of the sequences that could be aligned in the same portion of the rDNA $16 \mathrm{~S}$ gene of seven phyla of Eubacteria group (Proteobacteria - alpha, gamma and delta, Chloroflexi, Actinobacteria, Acidobacteria, Planctomycetes, Bacteroidetes, and Firmicutes). However, $40 \%$ of the sequences could not be classified in these phyla (Figure 3). Only eight clones were similar to known sequences of $16 \mathrm{~S}$ rRNA of cultivable organisms or environmental clones and could therefore be identified to the genus level (Table 3).

Table 3. Clones classified to genus level.

\begin{tabular}{lcc}
\hline Clone number (accession number $\left.{ }^{\mathrm{a}}\right)$ & Nearest microorganisms $^{\mathrm{b}}$ & \% Sequence identity \\
\hline Clone 1 (EF088453) & Planctomyces & 60 \\
Clone 11 (EF088442) & Acetivibrio & 100 \\
Clone 21 (EF088441) & Porphyrobacter & 88 \\
Clone 22 (EF088438) & Caldilinea & 100 \\
Clone 23 (EF088434) & Caldilinea & 91 \\
Clone 31 (EF088461) & Caldilinea & 97 \\
Clone 40 (EF088470) & Isosphaera & 100 \\
Clone 52 (EF088482) & Mycobacterium & 82 \\
\hline
\end{tabular}

${ }^{a}$ Accession numbers of the sequences in the GenBank database. ${ }^{b}$ Derived from the taxonomic analysis with the Naive Bayesian Classifier, using the default threshold of $80 \%$.

\section{DISCUSSION}

Direct lysis by maceration with liquid nitrogen proved to be efficient for landfarm soil analysis. The extracted DNA could be analyzed by molecular methodology such as DGGE and cloning assay. These molecular analyses were used to confirm the efficiency of the method described in this paper. Protocol $I-A$ also works for different soil compounds: clay soils from Atlantic Rainforest and sandy soils from mangrove and caatinga (data not shown). Mechanical lysis with liquid nitrogen is a simple and common process used for DNA extraction from plants (Doyle and Doyle, 1991) and has been used by Volossiouk et al. (1995) for soils, but the use of the detergent SDS was necessary in the subsequent steps of DNA extraction. Our protocol does not use detergents, and it is an advantage because detergents may inhibit DNA polymerase (Simmon et al., 2004). Nevertheless, maceration with liquid nitrogen is a harsh method, which can cause some DNA shearing. This procedure must be adjusted to promote cell lysis only, because excess maceration increases the risk of DNA shearing and releases more humic substances from soil. This fact reinforces the need for the subsequent DNA purification step.

Simmon et al. (2004) described an innovative protocol for the preparation of isolated bacterial PCR-template DNA using autoclaving as a lysis method. This protocol eliminates the use of detergents, organic solvents and mechanical cell disruption approaches, such as rapid heating and depressurization in an autoclave, and significantly reduces processing and costs of bacterial lysis. For isolated bacteria, the autoclave method produces amplifiable PCR template comparable or superior to seven other established methods of DNA template preparation, which include different detergents, enzymes and mechanical lysis method components (Simmon et al., 2004). However, this method has not been tested for direct DNA extraction of 
environmental samples, which require a standardized technique in accordance with the sample to be analyzed. The other protocol tested here, using three methods for cell lysis (Protocol II), was not efficient for the extraction of DNA from the Brazilian landfarm soil (Figure 1A). This was probably due to the presence of contaminants, such as some petroleum derivates that inhibit enzymatic reactions necessary to carry out this protocol.

Besides comparing different methods for cell lysis, the present investigation also compared two protocols for DNA extraction using phenol-chloroform-isoamyl alcohol (25:24:1), Protocol I-A, and $5 \mathrm{M}$ guanidium isothiocyanate added to $1 \mathrm{~mL}$ chloroform-isoamyl (24:1), Protocol I-B. Perhaps due to a greater amount of organic matter, the extraction of total DNA from the Soil 1 sample was only possible using phenol-chloroform-isoamyl alcohol. For the soil enriched with petroleum for six months, both extraction methods (using phenol-chloroform-isoamyl alcohol or guanidium isothiocyanate added to chloroform-isoamyl) were efficient (Figure 1A). This result reinforces the idea that a universal protocol for soil-DNA extraction is impractical, as every type of sample requires optimization of the extraction method (Zhou et al., 1996; Harry et al., 1999; Roose-Amsaleg et al., 2001).

All extraction products obtained by Protocols $I-A$ and $I-B$ could be amplified with the primers for 16S rDNA (Figure 1B and C). Because even trace amounts of humic materials and hydrocarbons inhibit PCR, the step of DNA purification with mini-columns of Sephadex G-200 and the additions of BSA and 2.85 U Taq DNA polymerase in PCR were necessary.

The protocol described here for total DNA extraction from disturbed soil proved to be extremely important for characterizing bacterial populations of landfarm soil by DGGE and cloning assay. The results of DGGE analysis showed 21-23 OTUs. According to Muyzer and Smalla (1998), DGGE gives a direct display of the predominant constituents in microbial assemblages. Knowledge of the microbial diversity and how it affects the functioning and sustainability of biodegrading processes in polluted soils remains the main challenge for environmental microbiologists. Although only $15 \%$ of the 51 clones had their sequences classified to the genus level, all the clones analyzed from landfarm soil demonstrated that this microbial community is phylogenetically diverse, with members of at least six different bacterial phyla (Figure 3). Since landfarm soil is a biological system used by petroleum refineries to bioremediate their residues, the bacteria present in the soil probably play an important role in the biodegrading processes. In this study, DGGE and the cloning assay were used as techniques to validate the DNA extraction methods. To study the microbial diversity of landfarm soil, more clones must be analyzed.

The impact of culture-independent studies on the petroleum biodegradation process is of crucial importance to the monitoring of the microbial community, as it allows the study of the ecological dynamics during different stages of biodegradation (Fernandez et al., 1999). Knowledge of the members of a certain microbial community can provide information about the diversity and metabolic activity of its inhabitants. Due to the growing concern over environmental preservation, detailed studies on petroleum-degrading microorganisms are very important and need to be conducted on landfarm soils of various places, since different niches possess different microbial communities. Studies on petroleum-degrading microorganisms are becoming more frequent due to their biotechnological importance for environmentalists and petrochemical industries. Therefore, the study of microbial diversity of petroleum-polluted areas of high priority and the standardization of an efficient protocol for total microbial DNA extraction in a particular niche are necessary initial steps for a detailed investigation. 


\section{CONCLUSION}

There are many different protocols for the extraction of DNA from soil samples, and all have advantages and disadvantages. The challenge is to choose the most effective one for the sample being analyzed, also bearing in mind the financial cost. Soil composition can interfere with the method used, and the development of a universal protocol for soil-DNA extraction may be difficult. Although many authors recommend the combination of the physical, chemical and enzymatic methods for cell lysis in soil samples, our results showed that the simple method of direct lysis by maceration with liquid nitrogen could yield large amounts of high-molecular weight DNA representing the total community of microorganisms. It was also possible to amplify total DNA with specific primers for the 16S rRNA gene for analysis by DGGE and cloning assay.

\section{ACKNOWLEDGMENTS}

Research supported by Conselho Nacional de Desenvolvimento Científico e Tecnológico (CNPq - Process No. 502697/2003-2) and the Universidade Estadual de Santa Cruz (UESC). The financial support granted to B.M. Maciel and A.C.F. Santos was provided by the Fundação de Amparo à Pesquisa do Estado da Bahia (FAPESB), Bahia State, Brazil. We thank Dr. Anthony Raw and Dr. Martin Brendel (UESC) for comments on the manuscript. We also thank Landulpho Alves Refinery (PETROBRAS), especially Mr. Ricardo Araújo, for collecting soil samples.

\section{REFERENCES}

Amann RI, Ludwig W and Schleifer KH (1995). Phylogenetic identification and in situ detection of individual microbial cells without cultivation. Microbiol. Rev. 59: 143-169.

Ausma S, Edwards GC and Gillespie TJ (2003). Laboratory-scale measurement of trace gas fluxes from landfarm soils. J. Environ. Qual. 32: 8-22.

Berthelet M, Whyte LG and Greer CW (1996). Rapid, direct extraction of DNA from soils for PCR analysis using polyvinylpolypyrrolidone spin columns. FEMS Microbiol. Lett. 138: 17-22.

Cole JR, Chai B, Farris RJ, Wang Q, et al. (2005). The Ribosomal Database Project (RDP-II): sequences and tools for high-throughput rRNA analysis. Nucleic Acids Res. 33: D294-D296.

Doyle JJ and Doyle JL (1991). Isolation of plant DNA from fresh tissue. Focus 12: 13-15.

Felsenstein J (1989). PHYLIP - Phylogeny Inference Package (Version 3.2). Cladistics 5: 164-166.

Fernandez A, Huang S, Seston S, Xing J, et al. (1999). How stable is stable? Function versus community composition. Appl. Environ. Microbiol. 65: 3697-3704.

Harry M, Gambier B, Bourezgui Y and Garnier-Sillam E (1999). Evaluation of purification procedures for DNA extracted from rich organic samples: interference with humic substances. Analusis 27: 439-441.

Heuer H, Krsek M, Baker P, Smalla K, et al. (1997). Analysis of actinomycete communities by specific amplification of genes encoding 16S rRNA and gel-electrophoretic separation in denaturing gradients. Appl. Environ. Microbiol. 63: 3233-3241.

Juck D, Charles T, Whyte LG and Greer CW (2000). Polyphasic microbial community analysis of petroleum hydrocarboncontaminated soils from two northern Canadian communities. FEMS Microbiol. Ecol. 33: 241-249.

Krsek M and Wellington EM (1999). Comparison of different methods for the isolation and purification of total community DNA from soil. J. Microbiol. Methods 39: 1-16.

Lane DJ (1991). 16S/23S rRNA sequencing. In: Nucleic acid techniques in bacterial systematics (Stackbrandt E and Goodfellow M, eds.). Wiley, Chichester, 115-176.

Li G, Huang W, Lerner DN and Zhang X (2000). Enrichment of degrading microbes and bioremediation of petrochemical contaminants in polluted soil. Water Res. 34: 3845-3853. 
Muyzer G and Smalla K (1998). Application of denaturing gradient gel electrophoresis (DGGE) and temperature gradient gel electrophoresis (TGGE) in microbial ecology. Antonie Van Leeuwenhoek 73: 127-141.

Ogram A, Sayler GS and Barkay T (1987). The extraction and purification of microbial DNA from sediments. J. Microbiol. Methods 7: 57-66.

Olsen GJ, Woese CR and Overbeek R (1994). The winds of (evolutionary) change: breathing new life into microbiology. J. Bacteriol. 176: 1-6.

Picard C, Ponsonnet C, Paget E, Nesme X, et al. (1992). Detection and enumeration of bacteria in soil by direct DNA extraction and polymerase chain reaction. Appl. Environ. Microbiol. 58: 2717-2722.

Roose-Amsaleg CL, Garnier-Sillman E and Harry M (2001). Extraction and purification of microbial DNA from soil and sediment samples. Appl. Soil Ecol. 18: 47-60.

Sheffield VC, Cox DR, Lerman LS and Myers RM (1989). Attachment of a 40-base-pair G + C-rich sequence (GC-clamp) to genomic DNA fragments by the polymerase chain reaction results in improved detection of single-base changes. Proc. Natl. Acad. Sci. U. S. A. 86: 232-236.

Simmon KE, Steadman DD, Durkin S, Baldwin A, et al. (2004). Autoclave method for rapid preparation of bacterial PCRtemplate DNA. J. Microbiol. Methods 56: 143-149.

Smalla K, Cresswell N, Mendoca-Hagler LC, Wolters A, et al. (1993). Rapid DNA extraction protocol from soil for polymerase chain reaction-mediated amplification. J. Appl. Bacteriol. 74: 78-85.

Steffan RJ, Goksoyr J, Bej AK and Atlas RM (1988). Recovery of DNA from soils and sediments. Appl. Environ. Microbiol. 54: 2908-2915.

Thompson JD, Higgins DG and Gibson TJ (1994). CLUSTAL W: improving the sensitivity of progressive multiple sequence alignment through sequence weighting, position-specific gap penalties and weight matrix choice. Nucleic Acids Res. 22: 4673-4680.

Tsai YL and Olson BH (1991). Rapid method for direct extraction of DNA from soil and sediments. Appl. Environ. Microbiol. 57: 1070-1074.

Tsai YL and Olson BH (1992). Rapid method for separation of bacterial DNA from humic substances in sediments for polymerase chain reaction. Appl. Environ. Microbiol. 58: 2292-2295.

Volossiouk T, Robb EJ and Nazar RN (1995). Direct DNA extraction for PCR-mediated assays of soil organisms. Appl. Environ. Microbiol. 61: 3972-3976.

Wang Q, Garrity GM, Tiedje JM and Cole JR (2007). Naïve Bayesian classifier for rapid assignment of rRNA sequences into the new bacterial taxonomy. Appl. Environ. Microbiol. 73: 5261-5267.

Wechter P, Williamson J, Robertson A and Kluepfel D (2003). A rapid, cost-effective procedure for the extraction of microbial DNA from soil. World J. Microbiol. Biotechnol. 19: 85-91.

Woese CR (1987). Bacterial evolution. Microbiol. Rev. 51: 221-271.

Zhou J, Bruns MA and Tiedje JM (1996). DNA recovery from soils of diverse composition. Appl. Environ. Microbiol. 62: 316-332. 